\title{
The Ghana Dance Ensemble in Perspective
}

\author{
Benjamin Obido Ayettey \\ bayettey@yahoo.com \\ Institute of African Studies, University of Ghana, Legon
}

\begin{abstract}
With the aim of preserving traditional music and dance through contemporary, theatrical and creative presentation, the Ghana Dance Ensemble in 1962 was initiated as an experiment between Ghana's educational and governmental systems. This paper is a historical account of the Ghana Dance Ensemble from the perspective of an 'insider' and historicity. The paper chronicles the evolution, successes, challenges and the role of the Ghana Dance Ensemble in Dance Education in Ghana. It also discusses the relationship that existed between the Ghana Theatre Movement and the Ghana Dance Ensemble in the realization of cultural consciousness in Ghana. The paper is more of a reflective study by someone who has been with the Ghana Dance Ensemble for over thirty years as a practitioner and a researcher.
\end{abstract}

Key words: Ghana Dance Ensemble, Ghana Dance Company, University of Ghana, traditional dances, choreography.

DOI: $10.7176 / \mathrm{JCSD} / 63-05$

Publication date: January $31^{\text {st }} 2021$

\section{Introduction and Background}

In many Ghanaian societies, as in most of West Africa, dance is an integral and important part of everyday social life. Soon after Ghana's independence, through President Nkrumah's National Theatre Movement policy, an effort was made to promote Ghanaian culture and unity through the performing arts. This gave birth the Ghana Dance Ensemble in association with the Institute of African Studies at the University of Ghana, Legon. The National Theatre Movement as conceived by Nkrumah gave birth to several performing arts groups across the country, emphasizing new productions of traditional materials wherever they existed under the auspices of the art Council of Ghana. Nkrumah believed that the cultural emancipation of Ghana in particular, and Africa in general, was linked to its indigenous arts. According to his philosophy, dance serves as a means of unification within the community, as well as a means of communication. Nkrumah also believed that the strong sense of community fostered through the traditional arts could work on a national level, contributing to the building and unification of the nation. In the year1959, he established a National Arts Council to foster, improve and preserve the traditional arts and culture of Ghana. The main aim of this council was to examine the practical ways and means to encourage a common National Theatre Movement, which on one level reflects the traditional heritage of Ghana and develops it into a living force firmly rooted in and acclaimed by Ghanaians and on the other serve as a repository of Ghanaian culture.

\section{Evolution of the Ghana Dance Ensemble}

Nkrumah, as a cultural nationalist, realized that one of the important ways by which a unified nation could be built was through the arts. To achieve this noble objective was to establish relevant institutions to suit his philosophical principles, whereby he incorporated the arts into a national agenda (Asamoah, 2005:181). Nkrumah was instrumental in the establishment of the Arts Council of Ghana, which served as a reservoir for preserving and protecting the indigenous cultures of the Ghanaian people. In 1955, Nkrumah directed the then Ministry of Education to set up a national theatre movement in the country. The prime objective of this movement was to bring together the cultures of various ethnics groups in the country so as to study and understand the cultures and traditions of the people. In June 1955, this became fruitful giving birth to the Arts Council of the Gold Coast to promote African indigenous cultural activities.

Cultural organizations including the Arts Council, The National Museum, The Ghana Library Board, The National Archives, and The National Cultural Centre in Kumasi were consolidated to ensure a more unified execution of Nkrumah's agenda. (Botwe Asamoah 2005:171-75). This noble agenda of nationalism made Nkrumah to extend his agenda to Schools, Colleges and the Universities, where Africans of all nationalities could be re-educated in 
an African- centered and socialist manner in order to produce freedom fighters and liberators of colonial oppression. Nkrumah had these national ideals generated in Achimota College. To realise this aim, In 1952, Kwabena Nketia and Ephraim Amu were appointed as research fellows at the Department of Sociology to collect and analyze a variety of African languages, music, dance and folklore in the then University of Gold Coast which was under the headship of David Balm.

Nketia stressed on the need to include cultural education at all levels of our education strata. He stated that

[t]he creation of modern states requires both cultural and material development. If we wait for these things to develop on their own, we run the risk of haphazard growth and aimless drift; the evident need therefore is for some form of institutional organization that will provide national integration through the artistic and other programs designed to encourage cultural interaction....in a national program for the arts. (Nketia 1987:185)

Along with the Africanisation of academic institutes came the creation the Institute of African Studies (IAS) by Kofi Abrefa Busia which was endorsed by Nkrumah and subsequently established in 1962, with Thomas Hodgkin as the first Director. At the inaugural ceremony Institute of African Studies, Nkrumah said,

One essential function of the Institute must surely be to study the history, culture, institutions and language and the arts of Ghana and of Africa in new African-centered ways in entire freedom from the propositions and presuppositions of the colonial epoch-by the work of the Institute, we must re-assess and assert the glories and achievements of our African past and inspire our generation, and succeeding generations, with a vision of a better future.

\section{Dance Education and the Ghana Dance Ensemble}

The introduction of Dance Theatre in Ghana has played an important role in promoting unity in the diversity. This dates back to 1962, when the School of Music and Drama and the Ghana Dance Ensemble was established at the Institute of African Studies, University of Ghana, Legon. This development was in response to a proposal made by the Institute of Art and Culture, chaired by Nana Kobina Nketsia IV, the Omanhene of Essikado Traditional Area for the formation of a single dance group to replace the various cultural groups which were transported to the capital city to present performances during national functions such as Independence Day celebrations. In terms of unifying the country, Nana Kobina's initiative encouraged the performances of various ethnic and regional dance forms of Ghana by a single group comprising members from diverse cultural backgrounds.

In line with this philosophy, Albert Mawere Opoku, who was an Art Lecturer at the University of Science and Technology, was charged with the responsibility of gathering traditional dances from all the Regions for preservation for posterity to promote cultural unity in the Country. This idea of forming a single Dance Company had already been mooted by Kwame Nkrumah in consultation with Rex Nettleford, the Director of the Jamaican National Dance Company, after Ghana's Independence in 1957 and so when the needed arose, it did not meet any stiff opposition. This move was to prevent Ghanaians from relying on foreign artistic forms all the time (Adinku1994:1). The School of Music and Drama began with twelve (12) students for the Dance Section who later formed the Ghana Dance Ensemble. At the inception of the School and the Ghana Dance Ensemble, the students travelled extensively to the various regions to research and study the indigenous dances. Mawere Opoku, who doubled as the Head of the Dance Section and Artistic Director of the Ensemble, talked to Chiefs and opinion leaders for the historical background of the dances, their origins, taboos, rituals associated with them, costumes, among other interesting aspects. He never failed to seek permission from the custodians to re-arrange these dances.

On October 28, 1967, the Ghana Dance Ensemble was formally inaugurated at the Arts Centre in Accra as the National Dance Company of Ghana by the then commissioner of Police (CID/SB), member of the National Liberation Council and commissioner for Sports, Arts and Culture, Mr. A.K. Deku who said, "If Ghanaian arts and culture are to survive and be meaningful to attract foreigners, then they must be kept alive. These arts and culture, must not be mere repetition of the same old-age rendition or by museum approach to the art, but by artistic imagination which clarifies their aesthetic values and renews their vitality."

In the Ghanaian Times published 13th November 1967, Mr. Deku again described the Ghana Dance Ensemble as one of the boldest experiments and one that represents a significant achievement in the creative effort to preserve our dances and to foster and develop our traditional arts and culture.

The Mission of the Ghana Dance Ensemble were

1. To help preserve and develop the traditional dance form of Ghana. 
2. To help develop a pool of professional dancers in the country.

The Ensemble had the following objectives:

1. To create opportunity for Ghanaians and the international community to share in the artistic heritage of Ghana in the area of dance and music.

2. To develop international co-operation through collaborative dance productions.

3. To help strengthen Ghana's cultural and artistic image through dance.

The dances were learnt in their raw form, and subsequently had them re-arranged to suit the stage and to satisfy the contemporary audience. Within five years, the Ghana Dance Ensemble had accumulated over 50 traditional dances including The Akan Ceremonial, Dagbani Dance Suites, Lobi, Anlo, Dahomeyan, and the Ga-Adangme Dance Suites, to mention but a few. Gradually, the Ghana Dance Ensemble became immensely popular due to its wide exposure and numerous performances with many well-endowed and trained dancers. The group assumed a professional status and concentrated on performance improvement and artistry. It was woven into a seamless fabric of unity in diversity as portrayed in the exquisite artistry of the Ghanaian Kente Cloth. Indeed, unless one had foreknowledge of the ethnic backgrounds of the performers, it was difficult to identify one's ethnic origin. For example, it was delightfully remarkable to watch performers like Patience Kwakwa, an Akan, perform Atsia Agbekor; Ampofo Duodu, an Akan, perform Ga Kpanlogo; William Ofotsu Adinku, an Adangme, perform Bawa from Upper West; and William Diku from Upper West, perform Akan Fontomfrom with dexterity and precision.

The Ensemble embarked on nationwide tours to showcase their collection. Preparatory to these important tours, each selected traditional dancer was required to thoroughly master particular dance forms from regions of the Country other than their own. Nii-Yartey (2006) posited that

[e]ach in turn taught the others dances from his or her own region, as did the musicians. Together they learned the rudiments of their art forms; including background information, the history and social functions of the dances.

After two years of research, training and experiments, Nkrumah sent the Ensemble on a tour of all regions of the country, taking along the 'transformed' traditional artistes to share the results with the various communities. In each region, the strategy was to ensure that within the company, the non-indigenous members outnumbered the indigenous ones during performances. Community leaders and local traditional rulers were often present at these performances. Interestingly, the audiences in most cases could not distinguish among the performers in terms of their ethnicity. The performers had to introduce themselves by name and their ethnic background before many of the spectators noticed the difference. As admitted by the Navro-Pio (1968), after one of such performances, "If anybody who does not come from my culture could devote his or her time and energy to learn and perform my dances so perfectly, that person must have a lot of respect for me and my people." Many of the spectators in other areas expressed similar sentiments throughout the many tours undertaken by the Ghana Dance Ensemble.

The observation made by the Navro-Pio and others attest to the fact that the Ghana Dance Ensemble experiment had a positive impact on efforts at unifying the people in their diverse ethnic strands towards nation building.

The Directors of the Ensemble since its inception is as follows:

$\begin{array}{llll}\text { 1. Prof. A.M. Opoku } & - & 1962-1976 \\ \text { 2. Prof. Francis Nii Yartey } & - & & 1976-1992 \\ \text { 3. Mr. E.A. Duodu } & & - & 1992-1996 \\ \text { 4. Mr. Nii KweiSowah } & - & & 1996-2002 \\ \text { 5. Mr. Benjamin O. Ayettey } & - & 2002-2016\end{array}$

\section{Achievements of the Ghana Dance Ensemble}

The Ghana Dance Ensemble under the Institute of African Studies has performed to roaring ovations by audiences and received raving reviews in the media on nearly all the continents of the world. With aesthetically pleasing 
dances that combine African folk and contemporary dance forms, the rich polyrhythm of percussion and mellifluous melodies, the Ghana Dance Ensemble proved itself a worthy Ambassador of Ghana.

The company marks the culmination of development initiated by the first President of the Republic of Ghana in 1962 when the Ghana Dance Ensemble was established in the Institute of African Studies under the directorship of Professor J.H. Nketia. The Ensemble was trained and developed by the Late Prof. Albert Mawere Opoku, the Artistic Director whose choreographed pieces and arrangements of traditional dances remained the standard repertoire of the Ensemble.

F. Nii-Yartey succeeded Prof. Opoku in 1976 as Artistic Director. In addition to the standard repertoire, he embarked on the development of his own concept of the African Dance Theatre, creating extended works that explore not only African Dance forms but also the polyvalent features of performance in African societies within the framework of the Dance Drama, an approach which has become the hallmark of the Ghana Dance Ensemble. The Ghana Dance Ensemble is very versatile. It can present a concert of traditional African arrangements of such dances and items from the standard repertoire as well as original extended works. It supports and collaborates with visiting artists and choreographers, for it is open to ideas and experiments that explore the potential of African dance forms.

In consonance with its aim of sharing the artistic heritage and potential of Africa with all nations, it has undertaken several international tours and has thrilled audiences at festivals like "Lamentation for Freedom Fighters" or Husago-Achia-Husago at the World Festival of Negro Arts in Dakar in 1966. The Ghana Dance Ensemble performed at the Liberty Stadium before a large audience. The choreography of the rich repertory entitled "African Dances", carefully designed and accompanied by excellent drumming, was particularly appreciated by the public. It was an undeniable fact, and one can say so without any fear of contradiction, that The Ghana Dance Ensemble was one of the best groups since the opening of the World Festival of Negro Arts.

The Ensemble has again received several standing ovations through their outstanding performances in the following countries: In 1983 the Ensemble toured France and Britain with its rich repertoire of dances and participated in World Festivals of Arts. In 1985 it participated actively in festival of arts in India and Botswana.

\section{The Establishment of the School of Music and Drama}

The pioneers of the Ghana Dance Ensemble played dual roles as drummers and dancers of the company. On October 22, 1962, there was an advertisement inviting applications from young men and women between the ages of eighteen and twenty-five for studentship in dance theatre studies leading to recruitment into the National Dance Company upon successful completion of a 2-year course. The same students formed the nucleus of the company, [while at the same time] undergoing training. It was linked to the research activities of the Institute of African Studies so as to enable serious research to be done by choreographers, performers and dance ethnologists; and it was assumed that findings would be properly documented and incorporated into the general concept of the institute as a research centre examining African traditions and suggesting areas in which changes could be made. The company also played a role in national unification by bringing people from various ethnic groups together to learn to perform one another's dances. In September 1962, the following were the pioneering members who started serious work: Patience Addo and Grace Nuamah assisted Prof. Nketia and Prof. Opoku, and they were later joined by Rose Atiega. In October 1962, the following were recruited to form the basis of the company: Beatrice Addo, Lily Acquah-Harrison, Matilda Attiane, Patience Abena Kwakwa, Emmerentia Tamakloe, Thomas Ekow Adi, William Ofotsu Adinku, Victor Clottey, Emmanuel Ampofo Duadu and Frank Kwesi Mensah. In February 1963, Godfrey Odokwei Sackeyfio joined them.

In 1964, upon the approval of the Syllabus by the Academic Board of the University of Ghana, came the School of Music and Drama where members of the company who had gone through two years' intensive practical training and those in possession of the Middle School Leaving Certificates were accepted as students for the course. From October 1964 to June 1965, students offered the following subjects for the final examination for the Certificate in Dance:

\section{A. Theory Papers}

1. Introduction of Movement Analysis and Notation

2. Studies in African Dance Forms

3. Theory of Music 
B. Practical Examination

1. Exercises and Reading in Labanotation Texts

2. Studies in African Dance Forms

3. Composition of Dance based on studies in African movements.

Out of the eight students, six of them were successful; they included Emmanuel Ampofo Duadu, Victor Clottey, Godfrey Odokwei Sackeyfio, William Ofotsu Adinku, Helen Mensah, and Lily Acquah-Harrison. At that time, Patience Abena Kwakwa and Emmerentia Tamakloe, had earlier on in September 1964 won an American undergraduate Scholarship for a Bachelor of Arts Degree in Julliard School of Music, but later transferred to the University of California, Los Angeles, and were for that reason not available for the Certificate in Dance Course.

When the Diploma came into existence, additional instructors and lecturers were appointed. They included Prof. J.H.Nketia who taught African Dance Forms, Drama in African Societies, Ghanaian Folklore and traditional African Songs. Prof. A.M. Opoku taught Labanotation, African Dance Forms, Movement aspect of Customary Behaviour and Choreography. Grace Nuamah taught Akan Dances and Songs, Seth Kobla Ladzekpo taught Ewe Dances and Songs. Instructors and Lecturers who joined later were Debora Berton from Israel who taught Movement/Dance Technique, Drid-Williams from U.S.A. taught Principles of Choreography, Dance History and Criticism, Modern Dance Technique, Odethe Blum from U.S.A. taught Labanotion, Modern Dance Technique, Prof. N.Z. Nayo taught Theory of Music, Sophia D. Lokko taught Dance and Theatre. Others included B.S. Kwakwa and Ama Aidoo who both taught English Language on part-time basis.

In April 1967, the Vice Chancellor of the University of Ghana, in order to streamline the operations of the Ghana Dance Ensemble, a school of Music, Dance and Drama and the Institute of African Studies set up a committee to investigate their academic and professional activities. Prof. Busia a former Ghanaian Professor of Sociology at Oxford University was invited as a one-member committee to study the issues and make recommendations. He suggested that the Ensemble should "remain part of the Institute to assist research as a demonstration group, and this, rather than only entertainment, should be its primary function."

The Ensemble staged traditional dances without destroying their essence. New methods of choreography were introduced. The ensemble worked on two fronts, performing in other African countries and also at home. This process demonstrated that dance could play a role in nation building and impressed educationists with the important role that dance could play in schools. The research fellows of the company and the institute continued to teach the dance to students of the school. In June 1968, Emmanuel Ampofo Duodu and Prof Willian Ofotsu Adinku emerged successfully and were subsequently employed as Principal Research Assistants Grade II in 1998. Due to their success, and also being the pioneering performers and students of the National Dance Company and the Dance Section of the school respectively, they were exposed to movement forms of major Ghanaian traditional dances. Materials for students' training were drawn from traditional sources so they became interested in dance as an element of culture.

\section{Training of Students at the School of Performing Arts}

One cannot talk about the training at the Ghana Dance Ensemble without mentioning or talking about that of the School of Performing Arts. Training at the school begins from the morning till evening everyday depending on what is on the time table. Lecturers and Teaching Assistants are assigned to various classes or levels to train the student dancers. Mr. Asare Newman, now a retired lecturer of the school, selects some movements from the traditional dances and use them as a movement technique, which he teaches during dance technique lessons. So when a student goes to the traditional dance lectures, he or she finds it easy because some of these movements in the traditional dances had already been learnt during the technique class. The lecturers apply the Analytic Simplification and Synthetic Coordination Concepts. The Analytic Simplification is the method by which the movement is broken into smaller units, thus making it easy for the learner to comprehend or pick with ease, and synthetic coordination is bringing the movements together to form a new thing. The students are also taught different traditional dances from the various regions of the country and stamina building during performances. 


\section{Dance Performance Laboratory (Dance Lab)}

The dance performance laboratory was introduced at the school as a combined class for Diploma students, where students learn traditional dances together. It has the following objectives:

1. To showcase the dances that had been learnt in class.

2. To help students remember the movements and sequence in the traditional dances taught.

3. To give students the opportunities to correct certain movements for which they have problems; it also makes them to build stamina.

4. To help juniors learn dances from their seniors so that when the former get to such levels they could find things easy.

5. The period is used to rehearse dances for productions.

6. Some students use the period to supporting drums.

\section{Training at the Ghana Dance Ensemble}

The present members of the Ghana Dance Ensemble rehearse every day from morning to evening, which becomes their normal duties. Junior performers are tasked to learn the dances and the drumming from their seniors or officers. They also learn choreographed pieces from their officers and perform them together with traditional dances on various occasions that they invite the group to perform.

\section{The Split: Ghana Dance Ensemble, Legon/Ghana Dance Ensemble, National Theatre}

When the current National Theatre Company of Ghana was formally created in 1992, the then chairman of the National Commission on Culture, Dr. Ben Abdallah, proposed that the three National dance companies, comprised of the Ghana Dance Ensemble, the Abibigromma Theatre Company and the National Symphony Orchestra, be moved to the National Theatre. The chairman's decision, however, did not sit well with individual members in the various national groups, especially the Ghana Dance Ensemble and the Abibigromma Theatre Company (resident companies of the University of Ghana). The members of the two companies were in a dilemma as to what would be their fate in the future, and wondered whether they would still benefit from the University of Ghana's free medical care and other fringe benefits. The members of the Ghana Dance Ensemble nominated two representatives to learn more from the university Assistant Registrar and the Registrar if they were aware of the relocation of the companies to the National Theatre. It was strange to the Registrar so he asked the nominees to see him the following day.

The following morning, the representatives returned for the feedback only for the Registrar to tell them that the Vice Chancellor did not know about the transition, and that the University was ready to continue taking care of the company, but that those who were interested in transitioning to the National Theatre should resign from the service of the University or else they would vacate their post after ten days of absence from work. That same day the Artistic Director summoned the members of both companies to a meeting where he briefed them about the transition to the National Theatre and concluded that even though the theatre itself was not fully completed, the Ensemble and Theatre Company would still have to move for the Chairman of the Commission on Culture to know that they were serious and ready to work for the National Theatre, and that a temporary place had been allocated to the two companies at the Ghana National Museum. They were asked to report to the Ghana National Museum the following day for National Assignment. This transition required the movement of office equipment, costuming, property, stage lighting, etc., to the Ghana National Museum.

After receiving their National Assignment, members were asked to report to the National Theatre for a meeting. The Artistic Director briefed members once again about the Commission's intention in moving the three companies to the National Theatre. After his explanation, he asked for questions. When nobody responded, he asked individuals by their names, "Are you ready to come and work at the National Theatre?" Those who remained 
with the company at Legon responded "We are thinking about it." He responded, "Then you belong to Legon." For a few of the older artistes and more of the newer ones, the answer was, "I am working here." One of the members during the question time answered that "Legon is my mother's house while the National Theatre is my father's house, so I am coming here." The Artistic Director was so excited with his answer and thinking that he could persuade the rest of the members with that sentiment jumped in and said, "Listen, listen, listen to Meriga, Meriga, say it again." Meriga then repeated his statement, but it did not change the minds of those who opted out.

Most of the older members chose to remain with the University of Ghana because they had served the company for over ten years and were concerned about whether they would be starting "from scratch" with the National Theatre. Upon requesting a condition of service from the National Theatre to determine whether it would be in their favor to serve with the National Theatre, the Artistic Director only provided verbal confirmation that their service would be a continuation of their service with the company at Legon and not a "new" role, but given the lack of written confirmation to serve as a record, these seasoned members opted out of service with the National Theatre.

Eventually sixteen dancers and drummers were left behind while fifteen officials, dancers and drummers went to the National Theatre. Those who went to the National Theatre resigned from the service of the Ghana Dance Ensemble, University of Ghana, Legon. The members that remained at Legon were:

Drummers

Foli Adade

Solomon Amanquandor

John Osci

Emmanuel Eku

Kwesi Nyantekyi
Male Dancers

William Oi Diku

Rocky Atsu Kporxah

Benjamin Obido Aycttey

Wisdom Agbedanu

Joseph Tetteh
Female Dancers

Faustina Dugbenu

Mary Atta

Mary Gyamcrah

Mercy Gyamerah

Philomina kwakye

\section{Emmanuel Tagoe}

Names of those resigned from the Ghana Dance Ensemble to the National Theatre (except the Artistic Director, who went on secondment) were:

Officials

Frances Nii Yartcy

Grace Dzabatey

Daniel Adokwei Moffatt

David Amoo

Juliana Hanson (Secretary)
Drummers

Afadena Atsikpa

Francis Kofi
Female Dancers

Patience Sewor

Peace Elewornu

Agnes Appiah

Doris Mensah

Caroline Yeme

Evelyn Akowiah

\section{Male Dancers}

Abukari Meriga

Felix Cheetham

Simon

\section{Electrician}

George Katey 
The split has since produced tensions between the National Theatre Company and the Ghana Dance Ensemble. Even though members of the National Theatre Dance Company resigned from the service of the University of Ghana where the Ghana Dance Ensemble is based, the National Theatre Company still uses the name "Ghana Dance Ensemble" for engagements, which confuses the public and clients.

After the split and the Artistic Director's secondment, none of the members was qualified to the Artistic Director position even though the members handled the affairs of the company because it is a position for senior members. Some of the members approached Ampofo Duodu, one of the pioneers of the Ghana Dance Ensemble and a senior lecturer at the School of Performing Arts then on retirement, to determine if he would be interested in working with the company. Upon his acceptance of this offer, his name was submitted to the Institute of African Studies Director who recommended him to the Registrar for the Acting Artistic Directorship position. He secured the position for four years from 1992 to 1996, after which it went to Nii Kwei Sowah, also a lecturer at the School of Performing Arts, who also manned the position for six years from 1992 to 2002 . Nii Kwei Sowah was succeeded by Benjamin Obido Ayettey in 2002 after successfully completing his Master of Fine Arts Degree in Dance Studies from the Arizona State University, USA.

\section{Choreographic Styles of the pioneer directors}

The Ensemble continues to perform in many national functions such as Independence Day celebrations, the swearing in of Ghana's new presidents and many more. The Ensemble also presented choreographed dances for the CAN 2005 and the International Hockey tournament. Much of its work is credited to regional tours in Ghana where the Ensemble educates students and the Ghanaian populace about HIV/AIDS with choreographed pieces. An example of such educational dance pieces is the "Dance of Joy and Sorrow," which was performed at CapeCoast University and the University of Ghana in 2005.

The ensemble's ovations continued to be outstanding, as Paul W. Schauet (2011) in an interview with Atsikpa (2006:67) maintained that "Opoku was a traditional man," and that he maintained the original ideals of the ensemble by working on traditional music and dance forms from the community and transferring them to the stage. However, Opoku always made sure that he did not put all ethnic dances together as one on stage as his paramount aim in his style of choreography was to retain the dances' distinctiveness. Some examples of his distinctive work include "Akan Ceremonial Dance Suit", the Anlo Dance Medley which was a combination of only Ewe pieces and that of the Lamentation for Freedom Fighters, and the Dagbani Dance Suit from selected dances among the Dagbamba in the Northern Ghana.

Nii-Yartey used the neo-traditional dance styles for his early choreographic works. An example of such style is the Lost Warrior in which he used only movements from the Agbekor dance among the Ewes. The King's Dilemma also uses dance movements from Northern Ghana, while Atopre movements were derived from Akan dances. Other choreographic works of Nii-Yartey that have neo-traditional dance influences and African Contemporary movements are Solma, Selyada, Images of Conflict and others.

Benjamin Ayettey's early works were also based on neo-traditional movements. These are seen in pieces like Kusum Gboo and Dance of Joy and Sorrow, while in Zahinle, Unity, and Solitude Liebe, etc., only African contemporary and modern dance movements were used. Therefore, Nii Yartey and Ben Ayettey's style of choreography are the same in terms of synthesizing various dance forms.

The Ensemble does not only perform outside the country but sometimes for visiting Heads of State in Ghana. The Ensemble in their performances excelled in unifying the people of different ethnic groups in Ghana. Ayettey (2005 $\mathrm{p}$ 76) emphasized that "Normally, when we go outside the country we do not perform dances from different [African] countries, because we need to promote our dances."

\section{Conclusion}

The establishment of the Ghana Dance Ensemble actually promoted national cultural cohesion by raising the level of cultural consciousness among audiences and spectators who watched the dance presentations. Watching Dance Theatre, helped audiences acquire some knowledge, which generated lively debates, discussions, criticisms, suggestions and interest. Nkrumah's idea of creating cultural consciousness among Ghanaians have of course been largely achieved through the activities of the Ghana Dance Ensemble. The Ghana Dance Ensemble has been very versatile; it has presented scores of traditional African dances over the years and has become the store house of rich dance repertoire for Ghana. It continues to support and collaborate with educational institutions, visiting 
artists and choreographers whiles opening avenues for new ideas and experiments to explore the potentials of African dance forms.

\section{References}

Abloso, A B (2013). The Promotion of Unity in Diversity through Dance Theatre: The Ghana Ensemble. (Ed) Helen Lauer, Nana Aba Appia Amfo and Joanna Boampong in "The One In The Many, Nation Building Through cultural diversity. Sub-Saharan Publishers.

Arhin, K. (1990). “Nkrumah's Cultural Policy. “In: The Life and Work of Kwame Nkrumah. Ed. Accra: SEDCO, $3-26$

Asamoah, KB (2005). Kwame Nkrumah's Politico-Cultural Thought and Policies. Routledge: New York.

Asante, S.K.B (2007). Ghana and the Promotion of Pan-Africanism and Regionalism. Accra: Ghana Academy of Arts and Sciences,

Badu, Younge, Zelma (2007). Through the eyes of an African Dancer: Intellectualizing the Body's Movement to music. The Talking Drum Newsletter issue No. 36: NETIEM Pan-African Society of Musical Art Education PASMAE.

Botwe, A.K (2005). KwameNkrumah's Politico-Cultural Thought and Policies An African-Centered Paradigm for the Second Phase of the African Revolution. New York: Routledge.

Dortey, M,N, Arhin A(2010) "The Performing Arts and the Post-Colonial Ghanaian Experience: The Ghana National Symphony Orchestra in Perspective.” Research Review New Series Vol. 26 No. 1

Ghana Dance Ensemble (1967). Office Files, Legon. Memo. “Ghana Dance Ensemble.” Retrieved on $5^{\text {th }}$ January 2018 .

Hagan, G. (1985) "Nkrumah's Cultural Policy." Paper Presented at the Symposium on the Life and Work of Kwame Nkrumah. University of Ghana, Legon.

Institute of African Studies (1992). Handbook of the 30th Anniversary Celebration of the Institute of African Studies and School of Performing Arts. Accra: University of Ghana Press.

Nketia, J.H (1964). "National Theatre Movements and the African Image." The Pan-Africanist Review 1(2):8-93

Opoku, A. M (1993) A bold Experiment.” In International Reviews of the Ghana Dance Ensemble, Ed. Legon: University of Ghana Press.

Opoku, A.M. "Choreography and the African Dance.” University of Ghana Institute of African Studies Research Review 3(1) (1978). 
Schauert, P. (2011). Staging Nationalism: Performance, Power, and Representation in Ghana's State Dance Ensemble. Ph.D. Dissertation, Indiana University of Ghana.

Yartey, N,F.(2009). The Performing Arts: Identity and the New Social Paradigm: Identity meets Nationality voices from the Humanities. Sub-Saharan Publishers. 